\title{
The influence of trait-emotional intelligence on authentic leadership
}

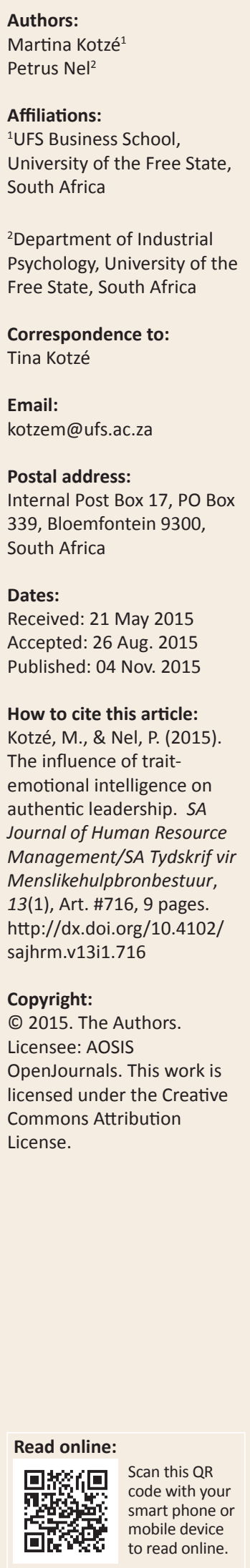

Orientation: Authentic leadership is a relatively new construct that has recently gained increasing attention resulting from challenges faced by organisations relating to ethical meltdowns, corruption and fraud.

Research purpose: This study seeks to explore the relationship between components of emotional intelligence and authentic leadership.

Motivation for the study: Several authors called for more empirical investigations into the antecedents of authentic leadership. Despite the important role that emotions play in leadership, empirical studies were lacking about the influence of different components of emotional intelligence to authentic leadership.

Research design, approach and method: Data were collected, using questionnaires obtained from 341 full-time employed applicants to MBA and leadership programmes in a South African Business School. Relationships between variables were analysed, using Pearson product-moment correlations and stepwise multiple regression.

Main findings: The results indicated that emotional intelligence has positive statistically significant associations with authentic leadership. Specifically, those who scored high on all the emotional intelligence components also scored high on authentic leadership. In addition, the emotional intelligence component of empathy was a statistically significant predictor of authentic leadership.

Practical/managerial implications: Initial findings suggest the potential value of recognising and developing the emotional intelligence of leaders to enable them to lead their organisations authentically to desired, successful outcomes. As empathy has been shown to be the most important emotional intelligence predictor of authentic leadership, leaders need to understand when subordinates perceive a leader as displaying empathic emotion.

Contribution: This study contributes to the literature and empirical research on the antecedents of authentic leadership.

\section{Introduction}

The challenges faced by public, private and even non-profit organisations relating to ethical meltdowns, corruption, accounting fraud, and IP infringement (Price Waterhouse Coopers, 2014), as well as the growing attention paid to corporate social responsibility (Lawler \& Ashman, 2012), have created a public need for organisational leaders who keep themselves accountable and who can lead with integrity, courage, and transparency (Diddams \& Chang, 2012). Leadership has always been more difficult in challenging times (Avolio \& Gardner, 2005) and, in the face of such pressures, people look for organisational leaders of character and integrity to provide direction, to help them find meaning in their work, and to restore confidence, hope, and optimism by relating genuinely toall stakeholders (associates, customers, suppliers, owners, and communities) (Avolio \& Gardner, 2005; Gardner, Avolio, Luthans, May \& Walumbwa, 2005). This type of leadership has been termed 'authentic leadership', referring to genuine leaders who lead by example in fostering healthy ethical climates, and who are not only true to themselves but who, likewise, lead others by helping them to achieve authenticity (Gardner et al., 2005). These leaders focus on their own moral compass and internal principles when facing unethical or ambiguous business practices (Diddams \& Chang, 2012).

Authenticity is seen 'as a broad psychological construct, reflecting one's general tendencies to view oneself within one's social environment and to conduct one's life according to one's deeplyheld values' (Ilies, Morgeson \& Nahrgang, 2005, p. 376). 'At more specific levels, authenticity is manifested in concrete aspects of one's' behaviour 'and existence, such as in leading others'. Avolio, Luthans and Walumbwa (2004) describe authentic leaders as: 
those who are deeply aware of how they think and behave and are perceived by others as being aware of their own and others' values/moral perspectives, knowledge, and strengths; aware of the context in which they operate; and who are confident, hopeful, optimistic, resilient, and of high moral character. (p. 4)

As first referenced in management and organisational literature, authenticity 'viewed the authentic capacity of a leader as a litmus test of executive quality' (Emuwa, 2013).

Authentic leadership has been associated with the following:

- promoting 'positive outcomes, such as' extra effort, increased trust, positive emotions, organisational commitment, and organisational citizenship behaviours (Dasborough, Todorova \& Qu, 2014; Peus, Wesche, Streicher, Braun \& Frey, 2012)

- employee creativity and innovativeness (Müceldili, Turan \& Erdil, 2013; Rego, Sousa, Marques \& Cunha, 2012)

- new venture performance (Hmieleski, Cole \& Baron, 2012)

- follower empowerment, commitment to and satisfaction with supervisors (Emuwa, 2013; Müceldili et al., 2013)

- eudaemonic well-being (Ilies et al., 2005).

Research has also indicated 'that authentic leadership may be particularly beneficial when shared among team members' within leadership teams (Hmieleski et al., 2012, p. 1479). In other words, although shared authentic leadership originates within individuals, it can also manifest as a team 'level property through members' common experiences, mutual interactions, and attraction-selection-attrition processes' (Hmieleski et al., 2012, p. 1479).

Because of the impact of everyday emotions on organisational life and the obvious demands for emotional labour inherent to the leadership role (Avolio, Gardner, Walumbwa, Luthans \& May, 2004; Gardner, Fischer \& Hunt, 2009; Humphrey, Pollack \& Hawver, 2008; Walter, Cole \& Humphrey, 2011), the role of emotions in leadership cannot be ignored. Gardner et al. (2009) state that:

although role demands of the leadership position and situational factors may create chronic needs for leaders to regulate emotions, acute events at work have the most immediate impact on a leader's emotions. (p. 469)

Subsequently, the role that positive emotions and trust may play in the authentic leadership process has been proposed by several researchers (Avolio, Gardner, Walumbwa, Luthans \& May, 2004; Gardner et al., 2005, 2009; Ilies et al., 2005; Walter et al., 2011). Those leaders who can effectively display and manage emotions, and who can accurately identify and understand others' emotions, can better observe the spirit of their employees (Vläsceanu, 2012). 'By tapping into the rich information that emotions provide, authentic leaders can often alter followers' thinking and' behaviour 'in ways that allow them to' negotiate organisational challenges more effectively (Avolio, Gardner, Walumbwa, Luthans \& May, 2004, p. 812). 'By working together on daily activities, leaders' and followers' emotions and moods converge through the process of emotional contagion'. Therefore, 'if authentic leaders experience more positive affective states (through self-awareness and relational orientation) than inauthentic leaders, their followers will experience more positive affective states' through emotional contagion (Ilies et al., 2005, p. 384). Gardner et al. (2009) argue that 'genuine emotional displays by a leader are positively related to the' favourability 'of follower impressions', and 'follower perceptions of leader authenticity'.

Given this fundamental role of emotions in leadership (Walter et al., 2011), emotional intelligence (EI) may be crucial in the authentic leadership process (Gardner et al., 2009). 'Emotionally intelligent individuals are posited not only' to 'be aware of their emotions, but' also to 'understand the causes and effects of such emotions on cognitive processes and decision making, and how' these 'change over time'. Theoretically, EI is expected to influence leadership outcomes through alternative channels, by enabling leaders to manage their own and their followers' feelings more effectively (Walter et al., 2011). Individuals with higher EI are likely to exhibit higher self-awareness (Ilies et al., 2005), thus:

[the] implication for authentic leadership development is that heightened levels of self-awareness will help leaders to understand and take into account their own and others' feelings, without being ruled by emotional impulses triggered by the moment. (Gardner et al., 2005, p. 353)

A study by Peus et al. (2012) supports empirically the proposition that the development 'of authentic leadership as perceived by followers is' related 'directly to the gaining of self-knowledge by the leader.' Furthermore, the results of their study show 'that followers evaluate leaders in terms of the consistency with which leaders behave in ways that are consonant with their core values or guiding purposes' (Peus, 2012, p. 343).

Research relating EI and authentic leadership specifically is basically non-existent (Gardner, Cogliser, Davis \& Dickens, 2011; Kiyani, Saher, Saleem \& Iqbal, 2013). Excluding the study by Kiyani et al. (2013), who examined the mediating effect of the authentic leadership style on the relationship between managers' EI (total score) and employee outcomes, no empirical studies relating to the direct relationship between components of EI and authentic leadership could be found. Walter et al. (2011) explain that, by examining the EIleadership link, scholars can promote further confidence in the relevance of EI, and contribute new insights that can assist educators, trainers, and management professionals in utilising emotional intelligence more effectively. Also, Gardner et al. (2011) 'called for more empirical investigations of the various antecedents' in authentic leadership, 'and, specifically, for further research that examines what components and situations develop a deeper understanding of the authentic leader-follower relationships' (Gardner et al., 2011, p. 1140).

\section{Research purpose}

In light of the above context, the purpose of the present research is to determine the influence of the various components of EI on authentic leadership. 


\section{Conceptualisation of authentic leadership}

A variety of approaches and interpretations representing a developing framework within which to understand the concept of authenticity and authentic leadership is evident from the literature (Eagly, 2005; Lawler \& Ashman, 2012; Liu, Cutcher \& Grant, 2015). 'The concept that dominates current' theorising, 'as well as empirical research, is the one proposed by Avolio and his colleagues' (Avolio, Gardner, Walumbwa, Luthans \& May, 2004; Gardner et al., 2005; Gardner et al., 2011; Ilies et al., 2005; Luthans \& Avolio, 2003; Walumbwa, Avolio, Gardner, Wernsing \& Peterson, 2008). Building on conceptualisations 'of authentic leadership by Avolio, Gardner and colleagues' (Avolio \& Gardner, 2005; Gardner et al., 2005) and Ilies et al. (2005), Walumbwa et al. (2008) 'define authentic leadership as 'a pattern of leader' behaviour 'that draws upon and promotes both positive psychological capacities and a positive ethical climate, to foster greater selfawareness', and internalised 'moral perspective, balanced processing of information, and relational transparency on the part of leaders working with followers, fostering positive self-development' (Walumbwa et al., 2008, p. 94).

The above authors propose that authentic leadership consists of four distinct but related substantive components: selfawareness, relational transparency, balanced processing, and internalised moral perspective. In this model of authentic leadership, self-awareness:

refers to showing an understanding of one's strengths and weaknesses and the multifaceted nature of the self, which includes gaining insight into the self through exposure to others, and being cognisant of one's impact on other people. (Walumbwa et al., 2008, p. 54)

'Relational transparency refers to presenting one's authentic self to others' and, therefore, promotes 'trust through disclosures that involve' sharing 'openly information and expressions of one's true thoughts and feelings whilst trying to' minimise 'displays of inappropriate' emotion (Walumbwa et al., 2008, p. 95). 'Balanced processing refers to leaders who show that they' analyse 'all relevant data' objectively before coming to a decision; they 'also solicit views that challenge their deeply-held' assumptions (Walumbwa et al., 2008, p. 95). Finally, internalised moral perspective refers to an internalised and integrated form of self-regulation that is 'guided by internal moral standards' and values as opposed to group, organisational, and societal pressures. This results in expressed decision making and behaviour that is consistent with these internalised values. According to Rego et al. (2012, p. 430), empirical evidence shows that a core authentic 'factor can emerge from the relationships' between these four dimensions. These 'individual factors do not add any meaningful incremental validity beyond the common core higher factor, suggesting that the variance attributable to' the overall authentic leadership construct 'is more important than the variance imputable to each individual dimension of the' authentic leadership construct. In essence, this means that it may be preferable to conceptualise authentic leadership as a unidimensional construct. Therefore, considering authentic leadership as a core construct is also conceptually plausible. The four authentic leadership 'dimensions are selfregulatory processes governed partially' by 'leaders' internal standards and their evaluations of their own' behaviour. The perspective on authentic leadership advanced by the above researchers recognises and articulates the central role of an internalised moral perspective on 'authentic leadership and its development. It focuses explicitly on the development of authentic leaders and authentic followers, which' makes it state-like and 'ultimately something one can develop in leaders' (Avolio \& Luthans, 2006; Luthans \& Avolio, 2003; Walumbwa et al., 2008).

Although authentic leadership shows some overlap with, and can incorporate different modern perspectives on, leadership, such as transformational, charismatic, servant, and spiritual leadership (Avolio \& Gardner, 2005; Diddams \& Chang, 2012; Kiyani et al., 2013), authentic leadership as a construct is gaining legitimacy in its own right (Kiyani et al., 2013). Avolio and Gardner (2005) stress that authentic leadership is more generic and represents a 'root construct' that provides the basis for other forms of positive leadership. Avolio and Gardner (2005):

believe the key distinction is that authentic leaders are anchored by their own deep sense of self; they know where they stand on important issues, values, and beliefs. With that base, they stay their course and convey to others, oftentimes through actions ... just words, what they represent in terms of principles, values, and ethics. (p. 329)

\section{Emotional intelligence}

The various models of EI are divided into three distinct categories (Ashkanasy \& Daus, 2005; Walter et al., 2011). The first category is referred to as the ability model (Mandell \& Pherwani, 2003; Van Rooy, Alonso \& Viswesvaran, 2005). The ability EI approach was introduced by Salovey and Mayer (1990), who view emotional intelligence as the ability of individuals to not only discriminate between different feelings and emotions experienced by themselves, but to also be able to monitor these feelings and emotions. Subsequently, these individuals use this information to guide their own thinking. This approach employs ability-based EI tests that capture individuals' performance in solving emotional problems (Fiori et al., 2014; Walter et al., 2011).

The second category also draws on Salovey and Mayer's definition, but rather than employing ability-based tests, it uses self-assessments or reports by others of emotional intelligent behaviour (Ashkanasy \& Daus, 2005; Walter et al., 2011). The third category is referred to as the so-called 'mixed models' (Brackett, Mayer \& Warner, 2004) or 'trait models' (Petridges \& Furnham, 2001). The trait models of emotional intelligence blend emotional intelligence as an ability with certain traits, competencies, and behaviour (Zeng \& Miller, 2003), 'and generally include broad arrays of non-cognitive factors, such as personality and motivation' (Brackett et al., 2004; Van Rooy et al., 2005). This approach regards EI as a dispositional tendency representing a conglomerate of 
cognitive, personality, motivational, and affective attributes, and usually makes use of self-assessments or other-report measures (Fiori et al., 2014; Mikolajczak, 2009). Both the Bar-On model of EI (Bar-On, 2000), as well as the emotional competence model of EI (Goleman, 1995, 1998; Goleman, Boyatzis \& McKee, 2002) are viewed as mixed models of EI.

Similar to the Bar-On model, Goleman's (1998) model also emphasises 'non-cognitive intelligence' (Muyia, 2009). Goleman's model is viewed as a 'performance-based' model, 'centered on the emotional development of workplace leaders'. It focuses on four dimensions:

1. 'self-awareness - the ability to recognize one's own feelings, abilities, and limitations'

2. 'relationship management - the ability to influence others, manage conflict, and inspire others'

3. 'social awareness - the ability to read the emotions of others (this also involves empathy)'

4. 'self-management - the ability to control one's own negative emotions and to be trustworthy' (Muyia, 2009, p. 692).

The trait EI perspective has been criticised, firstly, for using self-reports which, critics contend, scarcely 'reflect selfperceptions and therefore constitute unreliable assessments of objective competencies'. Secondly, it has been criticised for correlating with existing personality traits too closely to be useful (Mikolajczak, 2009). Nonetheless, after examining different EI ability and self-report measurement instruments, and exploring the 'relationships of EI factors with other cognitive abilities and personality dimensions', Barchard and Hakstian (2004) conclude that 'self-report measures are better understood as measures of self-perceptions of abilities than as measures of EI abilities themselves'. Selfreport measures 'are not associated with the same factors as maximum-performance tests that putatively measure the same constructs, and they' correlate 'with personality dimensions but not with cognitive abilities (Barchard \& Hakstian, 2004, p. 460)'.

In support of this argument, Davies, Lane, Devonport and Scott (2010) state that self-report measures add value in that they do not contradict the subjective nature of emotions. Collecting data relating to self-perceptions may be useful in itself for two reasons. Firstly, if a person's selfconcept is accurate, his or her perceived emotional skills and abilities may be predictive of actual skills and abilities (Brackett \& Geher, 2006). Secondly, because people tend to act according to their stated beliefs (Bandura, 1997), selfreported scores may be predictive of actual performance in a particular context (Davies et al., 2010). In response to criticism relating to the unreliable assessments of objective competencies in the case of trait EI, Mikolajczak (2009) states that this argument proves to be incorrect, as trait EI does relate to objective criteria. As trait EI has neurobiological correlates, not only does it correlate with the speed of emotional information processing (Austin, 2005), but it also predicts objective life-outcomes, such as work performance, income, and cooperation (Mikolajczak, 2009). The critique which argues that trait EI correlates too closely with existing personality traits to be useful is also refuted by various studies, such as that of Tett, Fox and Wang (2005), which show that trait EI is distinct from other dispositional domains, such as personality traits. According to these authors, self-reports offer reliable and valid means of assessing trait EI. Joseph and Newman (2010) confirm these results as their study also showed that trait EI explains additional variance over and above related traits, such as the Big Five personality factors.

\section{Research design Research approach}

In order to execute the research, the current study followed a cross-sectional design with a survey data collection technique.

\section{Research method Research participants}

A total of 341 aspiring Business School students in full-time employment who had applied for MBA and leadership programmes participated in the study. Males $(n=206)$ were in the majority $(60.4 \%)$, compared with 135 females (39.6\%). The age of these participants had the following ranges:

- $25.5 \%$ from $31-35$ years (the majority age group)

- $22.9 \%$ from $26-30$ years

- $22.0 \%$ from $36-40$ years

- $15.0 \%$ from $41-45$ years

- $8.8 \%$ from $46-50$ years

- $4.7 \%$ from $21-25$ years

- $1.2 \%$ were older than 50 years.

Additional information regarding the sample can be found in Table 1.

\section{Measuring instruments}

Authentic Leadership: AL was measured using the Authentic Leadership Questionnaire (ALQ) (Walumbwa et al., 2008). Grounded in the perspective of authentic leadership by Avolio, Gardner, Luthans, May, Walumbwa

TABLE 1: Additional biographical information of sample.

\begin{tabular}{llcc}
\hline Variable & Sub-dimensions & Frequency & $\mathbf{\%}$ \\
\hline Language & Afrikaans & 105 & 31 \\
& SeSotho & 102 & 30 \\
& SeTswana & 43 & 12 \\
& Other language group (including English, & 91 & 27 \\
& IsiXhosa, IsiZulu, Sepedi, Tsonga, etc.) & & \\
Tertiary & Diploma & 135 & 40 \\
Qualification & B-degree & 90 & 26 \\
& Postgraduate diploma & 24 & 7 \\
& Other qualification & 92 & 27 \\
Employment & Public & 120 & 35 \\
Sector & Private & 182 & 53 \\
& Other & 39 & 12 \\
\hline
\end{tabular}


and colleagues (Avolio \& Gardner, 2005; Gardner et al., 2005). The questionnaire is the instrument most frequently used as a measure of authentic leadership (Gardner et al., 2011). The ALQ consists of 16 five-point items, and measures four dimensions: self-awareness, relational transparency, internalised moral perspective, and balanced processing. Items include statements such as 'seeks feedback to improve interactions with others' (self-awareness); 'says exactly what he or she means' (relational transparency), 'demonstrates beliefs that are consistent with actions' (internalised moral perspective) and 'listens carefully to different points of views before coming to conclusions' (balanced processing). Individuals report the frequency (0: 'not at all'; 4: 'frequently, if not always') with which they adopt the 16 behaviours and attitudes.

\section{Emotional intelligence}

EI was measured using the Rahim Emotional Quotient Index (REQI). It is a multidimensional measure of trait EI, and was developed using the dimensions of EI proposed by Goleman (1995). It is a self-assessment survey for both subordinates and supervisors to evaluate either their own level of emotional intelligence or the emotional intelligence of their supervisors (Abas, 2010; Rahim et al., 2002). The self-rating instrument requires respondents to provide their opinions about the way they perceive themselves in relation to Goleman's five dimensions of emotional intelligence. These dimensions are (Rahim et al., 2002, p. 305):

- Self-awareness: 'The ability to be aware of which emotions, moods, and impulses one is experiencing, and why'. This dimension is also indicative of an individual's awareness of the effects his or her feelings have on others.

- Self-regulation: 'The ability to keep one's own emotions and impulses in check, and to remain calm and composed in volatile situations, irrespective of one's emotions'.

- Motivation: 'The ability to remain focused on goals, despite setbacks. This dimension also indicates an individual who is able to operate from hope for success rather than a fear of failure'.

- Empathy: 'A person's ability to understand the feelings conveyed through verbal and non-verbal messages, providing emotional support when needed, and to understand the connection between others' emotions and behaviour'.

- Social skills: 'The ability of' individuals 'to handle problems without demeaning others who work with them'. This dimension 'also includes the ability to refrain from letting one's own negative feelings towards another individual inhibit collaboration, and to handle conflict with tact and diplomacy'.

- $\quad$ The 'instrument uses a 7-point Likert scale (7 = Strongly Agree ... 1 = Strongly Disagree ...) for ranking each item, a higher score' indicates a greater dimension of Emotional intelligence. Examples of statements included in the survey are: 'I keep my distressing emotions in check' and 'I understand the link between employees' emotions and what they do' (Abas, 2010).

\section{Statistical analysis}

The study employed LISREL 8.80 (Jöreskog \& Sörbom, 2006) to estimate the goodness-of-fit associated with each of the two constructs (EI and authentic leadership). To determine whether the data was skewed, a test of multivariate normality should be performed (Jöreskog \& Sörbom, 2006). This test indicated that the data was indeed skewed which required the current study to use the robust maximum likelihood method of estimation (Brown, 2006, pp. 65, 347). Additionally, several fit indices were used, including the Satorra-Bentler Scaled Chi-square, Root Mean Square Error of Approximation (RMSEA), Standardised Root Mean Square Residual (SRMR), Comparative Fit Index (CFI), and the Goodness-of-Fit Index (GFI). Values close to 0.95 for GFI and CFI are considered indicative of good model fit. According to $\mathrm{Hu}$ and Bentler $(1999$, p. 1) a model has acceptable fit when the values for RMSEA are close to 0.06 , while values smaller than 0.08 are acceptable for SRMR. In estimating the reliability associated with the dimensions of the two constructs (EI and authentic leadership), Cronbach's alpha $(\alpha)$ was calculated. Estimates exceeding 0.6 are deemed acceptable (Hair, Black, Babin, Anderson \& Tatham, 2006, pp. 137, 778). The Pearson product-moment correlation was used to investigate the degree to which the dimensions of emotional intelligence are significantly correlated with authentic leadership. In addition, Guilford's informal interpretation of $r$ was used to interpret the strength of the obtained correlations (Tredoux \& Durrheim, 2002). To determine which of the components of EI are significant predictors of authentic leadership, stepwise multiple regression was used (Field, 2005).

\section{Results}

The results section consists of five tables encompassing the statistical outcomes from the collected data, followed by a short report. Table 2 and Table 3 report on the psychometric properties (goodness-of-fit statistics and Cronbach's alpha coefficients). Table 4 presents the correlations between variables. Tables 5-6 show the results of the stepwise multiple regression analysis with EI components as the predictors of authentic leadership.

\section{Psychometric properties of the instruments}

From Table 2 it is evident that the REQI shows acceptable levels of fit when considering the RMSEA, SRMR, and CFI. The Authentic Leadership Questionnaire also exhibits acceptable fit when looking at both the CFI and SRMR.

TABLE 2: Goodness-of-fit statistics.

\begin{tabular}{lcc}
\hline Fit index & Emotional intelligence & Authentic leadership \\
\hline S-B X & 566.07 & 265.14 \\
df & 395 & 98 \\
RMSEA & $0.036 \dagger$ & $0.071 \ddagger$ \\
CFI & 0.99 & 0.95 \\
SRMR & 0.037 & 0.082 \\
\hline
\end{tabular}

†, $(0.029 ; 0.042) ; \ddagger 0.061 ; 0.081$. 
TABLE 3: Reliability estimates.

\begin{tabular}{lcc}
\hline Variable & Number of items & Cronbach's alpha \\
\hline Transparency (Authentic Leadership) & 5 & 0.60 \\
Moral/Ethical (Authentic Leadership) & 4 & 0.78 \\
Balanced Processing (Authentic Leadership) & 3 & 0.43 \\
Self-Awareness (Authentic Leadership) & 4 & 0.76 \\
Self-Awareness (Emotional Intelligence) & 6 & 0.91 \\
Self-Regulation (Emotional Intelligence) & 6 & 0.91 \\
Motivation (Emotional Intelligence) & 6 & 0.93 \\
Empathy (Emotional Intelligence) & 6 & 0.90 \\
Social Skills (Emotional Intelligence) & 6 & 0.91 \\
\hline
\end{tabular}

TABLE 4: Correlations between components of emotional intelligence and authentic leadership.

\begin{tabular}{lc}
\hline Variable & Authentic leadership (Total) \\
\hline Self-Awareness & $0.23 \dagger$ \\
Self-Regulation & $0.22 \dagger$ \\
Motivation & $0.15 \dagger$ \\
Empathy & $0.24 \dagger$ \\
Social Skills & $0.23 \dagger$ \\
\hline
\end{tabular}

$\dagger$, Correlation is significant at the 0.001 level.

The majority of the variables have acceptable reliability estimates - see Table 3. However, the balanced processing component of the authentic leadership construct may leave room for improvement $(\alpha=0.43)$.

\section{Correlations between emotional intelligence components and authentic leadership}

It is evident from Table 4 that all the components of EI are significantly correlated to authentic leadership. More specifically, empathy has the strongest relationship with authentic leadership whilst motivation has the weakest relationship with authentic leadership. Using Guilford's informal interpretation of $r$, it is clear that the majority of the correlations ( 0.20 and higher) can be interpreted as low correlations, and definite but small relationships. These results show that those individuals who have higher levels of EI also view themselves as more authentic leaders.

\section{Emotional intelligence components as predictors of authentic leadership}

To determine whether or not any of the EI components are significant predictors of authentic leadership, the results of the stepwise multiple regression need to be consulted (see Tables 5-6). From Table 5 it is evident that three components of EI are significant predictors of authentic leadership. However, the sign associated with the regression coefficient for motivation is reversed. This result was unexpected, given that the bivariate correlation between motivation and authentic leadership is positive. As multicollinearity may be the reason for this, further investigation into the variance inflation factor (VIF) as well as tolerance was necessary. Evidence of multicollinearity is observed by determining both the VIF as well as tolerance (Hair et al., 2006). Variables with the lowest tolerance and the highest VIF may be removed to improve the interpretation of the regression model. Hence, after further investigation, the variable motivation was removed from the second stepwise multiple regression model.
TABLE 5: Stepwise multiple regression.

\begin{tabular}{lccccccc}
\hline Variable & $\boldsymbol{\beta}$ & $\begin{array}{c}\text { Standard } \\
\text { error }\end{array}$ & $\boldsymbol{t}$ & $\boldsymbol{p}$ & $\begin{array}{c}\text { Cumulative } \\
\boldsymbol{R} \text {-square }\end{array}$ & Tolerance & VIF \\
\hline Empathy & 0.36 & 0.11 & 3.33 & 0.00 & 0.06 & 0.22 & 4.57 \\
Motivation & -0.37 & 0.11 & -3.29 & 0.00 & 0.08 & 0.10 & 5.53 \\
Social Skills & 0.25 & 0.11 & 2.36 & 0.01 & 0.09 & 0.22 & 4.67 \\
\hline
\end{tabular}

TABLE 6: Stepwise multiple-regression (revised).

\begin{tabular}{lcccc}
\hline Variable & $\boldsymbol{\beta}$ & Standard error & $\boldsymbol{t}$ & $\boldsymbol{p}$ \\
\hline Empathy & 0.24 & 0.05 & -3.65 & 0.00 \\
\hline
\end{tabular}

From Table 6 it is evident that after the removal of the EI variable motivation from the multiple regression model (resulting from multicollinearity), EI empathy was the only significant predictor of authentic leadership. It explained $6 \%$ of the variance $(F=21.63, p=0.00)$.

\section{Discussion Outline of the results}

The purpose of the present study was to examine the influence of the various components of EI on authentic leadership. Broadly speaking, the results showed that trait EI was positively linked to authentic leadership. Six percent of the variance in authentic leadership could be explained by one of the EI components, namely, empathy.

Empathy showed the strongest relationship to authentic leadership and also contributed the most to authentic leadership. This finding supports both theoretical arguments (Butler \& Chinowsky, 2006; Humphrey et al., 2008; Mahsud, Yukl \& Prussia, 2010; Riggio \& Reichard, 2008) and prior empirical research (Rubin, Munz \& Bommer, 2005; Sadri, Weber \& Gentry, 2011) relating empathy to other leadership behaviours and styles. Prior research (Kellett, Humphrey \& Sleeth, 2006) indicated a significant correlation between empathy and both task-oriented and relations-oriented leadership behaviour. Furthermore, a study by Sadri et al. (2011) shows that leaders who are rated by their subordinates as engaging in behaviour that signals empathic emotion are perceived as better performers by their bosses. Several other studies found a strong relationship between empathy and transformational leadership (Butler \& Chinowsky, 2006; Rubin et al., 2005).

In light of the above, it makes sense that leaders with high empathy are more able to recognise when different relations behaviours are relevant (Mahsud et al., 2010) for example: to know when to be more supportive, encouraging, and helpful if a subordinate is anxious or overstressed by the pressures of the job, or to be able to detect any underlying feelings of injustice and resentment about assignments, rewards, and support from the leader. Humphrey et al. (2008) state that an emotionally intelligent leader may be capable of expressing authentic sympathy and support toward frustrated followers, whilst Riggio and Reichard (2008) argue that emotional sensitivity, originally conceptualised as leader empathy (Bass, 1960, 1990) allows leaders to gauge the emotional reactions and 
general emotional tone of a group. These authors propose that leader emotional sensitivity is positively associated with high quality leader-member relationships, and is also associated with better assessment of negative moods amongst followers. As authentic leadership places a high premium on the fostering of a strong relationship between a leader and individual followers (Riggio \& Reichard, 2008), as well as focusing on understanding those whom they serve (Diddams \& Chang, 2012), the role of empathy in authentic leadership is evident.

EI social skills also showed a significant relationship with self-perceived authentic leadership. Social skills, as measured in this study, include refraining from one's own negative feelings towards another individual in order not to inhibit collaboration, and to handle conflict with tact and diplomacy. This finding does not come as a surprise as several researchers have emphasised the relational nature of authentic leadership (Avolio \& Gardner, 2005; Eagly, 2005), and the importance of viewing oneself within one's social environment (Ilies et al., 2005). Also, the role that positive emotions and trust may play in the authentic leadership process (Avolio, Gardner, Walumbwa, Luthans \& May, 2004; Gardner et al., 2009; Walter et al., 2011), as well as the ability of the leader to manage emotions in this relationship with followers (Vläsceanu, 2012), relate to these findings. Prior research regarding conflict handling and leadership showed a positive relationship between effective conflict management and authentic leadership. A study by Maldonado (2012) explored the relationship between leadership style and effective conflict management in healthcare organisations. The results of the qualitative study indicated that the transformational and authentic leadership styles are most effective in implementing approaches to conflict resolution, whilst leaders who have higher EI and better communication skills are more effective in managing conflict.

The role of self-awareness, and self-regulation in authentic leadership was also evident. Several researchers (Avolio \& Gardner, 2005; Dasborough et al., 2014; Gardner et al., 2005; Walumbwa et al., 2008) emphasised the importance of selfawareness, self-knowledge, and self-regulation in authentic leadership. The results of this study showed that there were statistically significant relationships between self-awareness and authentic leadership, and self-regulation and authentic leadership. These results were expected, as emotional selfawareness is essential in the understanding of one's self and in the understanding and management of others (Hopkins, O'Neil \& Williams, 2007). Peus et al. (2012) examined selfknowledge and self-consistency as antecedents of authentic leadership. The results of their empirical study indicated that both self-knowledge and self-consistency can be regarded as antecedents of authentic leadership. Diddams and Chang argue that it is not always possible to judge one's own level of self-awareness. 'Rather than equate self-awareness with extensive self-knowledge alone, they suggest that authentic leaders are also more aware of their own ambiguities, inconsistencies, and limits to self-knowledge'. There should be the realisation that one's self-knowledge will always be incomplete (Diddams \& Chang, 2012, p. 597).

\section{Practical implications}

Since EI empathy has been shown to be the most important EI predictor of authentic leadership, leaders need to understand when subordinates perceive a leader as displaying empathic emotion. Therefore, in order to develop authentic leaders, it may be meaningful to identify how empathy manifests in the workplace, as no detailed descriptions of empathy behaviour in the workplace exist. This research also suggests that emotional and social skills are both related to authentic leadership, therefore, we suggest that, at a more practical level, emotional and social skills can be targeted for assessment and development, and can be an important component of an authentic leadership development programme. Executive coaching can be used to improve interpersonal skills, such as empathy, whilst multisource feedback programmes, including role modelling and leadership training interventions, can be used to increase self-awareness and assist leaders to obtain a deeper understanding of their strengths and weaknesses and improve 'relations behaviours'.

\section{Limitations and recommendations}

The results presented in this article should be understood within the context of the limitations of the study. Firstly, EI was measured by means of self-reporting which can be subjected to biases. 'However, since this study was largely concerned with self-perceptions, the use of such self-reports is not unreasonable' (Schmitt, 1994, p. 393). Furthermore, 'common source bias poses a potential problem in this study, since all variables are based on' self-assessment. Therefore, as further studies have not provided additional support for the influence of EI on authentic leadership, it should not be used to inform selection decisions. 'In future studies, it may be fruitful to complement data' with additional data from different sources, such as the perceptions of followers. In terms of future research, it is recommended that perhaps the different components of both EI and authentic leadership can be assessed using the above means, instead of using a composite score for authentic leadership. This may create deeper insight into the relationships between the different components embedded in both these constructs. It is especially important to define the different components of EI measured clearly in order to enable the comparison of the results of different empirical studies. Further, qualitative follow-up studies may provide more depth to clarify and discuss the nature of the relationships identified.

\section{Conclusion}

Little empirical work exists on the antecedents of authentic leadership. This study contributes much-needed empirical evidence in support of various components of EI and its relationship to authentic behaviour. These results support 
theoretical arguments that authentic leaders are more sensitive interpersonally and, therefore, measure higher on empathy and social skills. It also supports the empirical and theoretical proposals that self-awareness and self-regulation may very well differentiate leaders' performance in authentic leadership behaviour. This study has provided the first empirical evidence on the components of EI as antecedents of authentic leadership which is particularly important since 'knowledge about the antecedents of authentic leadership provides a foundation for authentic leadership development' (Peus et al., 2012, p. 332).

\section{Acknowledgements Competing interests}

The authors declare that they have no financial or personal relationships which may have inappropriately influenced them in writing this article.

\section{Authors' contributions}

M.K. (University of the Free State) was responsible for the conceptualisation, literature review, data-gathering, and discussion of the results. P.N. (University of the Free State) executed the research design, statistical analysis, and also wrote that section of the article.

\section{References}

Abas, N.A.H. (2010). Emotional intelligence and conflict management styles. Unpublished research paper: Master of Science Degree in Applied Psychology, The Graduate School, University of Wisconsin-Stout, Menomonie, Wisconsin: United States of America.

Antonakis, J., Ashkanasy, N.M., \& Dasborough, M.T. (2009). Does leadership need emotional intelligence? The Leadership Quarterly, 20, 247-261. http://dx.doi org/10.1016/j.leaqua.2009.01.006

Ashkanasy, N.M., \& Daus, C.S. (2005). Rumors of the death of emotional intelligence in organizational behavior are vastly exaggerated. Journal of Organizationa Behavior, 26, 441-452. http://dx.doi.org/10.1002/job.320

Austin, E.J. (2005). Emotional intelligence and emotional information processing. Personality and Individual Differences, 39, 403-414. http://dx.doi.org/10.1016/ j.paid.2005.01.017

Avolio, B.J., \& Gardner, W.L. (2005). Authentic leadership development: Getting to the root of positive forms of leadership. The Leadership Quarterly, 16, 315-338. http://dx.doi.org/10.1016/j.leaqua.2005.03.001

Avolio, B.J., Gardner, W.L., Walumbwa, F.O., Luthans, F., \& May, D.R. (2004). Unlocking the mask: A look at the process by which authentic leaders impact follower attitudes and behaviors. The Leadership Quarterly, 15, 801-823. http://dx.doi. attitudes and behaviors. The Leaders
$\mathrm{org} / 10.1016 / \mathrm{j}$. leaqua.2004.09.003

Avolio, B.J., \& Luthans, F. (2006). The high impact leader: Moments matter for accelerating authentic leadership development. New York: McGraw-Hill.

Avolio, B.J., Luthans, F., \& Walumbwa, F.O. (2004). Authentic leadership: Theorybuilding for veritable sustained performance. Working paper. Gallup Leadership Institute, University of Nebraska-Lincoln, Lincoln NE

Bandura, A. (1997). Self-efficacy: The exercise of control. New York: W.J. Freeman.

Barchard, K.A., \& Hakstian, A.R. (2004). The nature and measurement of emotional intelligence abilities: Basic dimensions and their relationships with other cognitive ability and personality variables. Educational and Psychological Measurement 64(3), 437-462. http://dx.doi.org/10.1177/0013164403261762

Bar-On, R. (2000). Emotional and social intelligence: Insights from the emotional quotient inventory. In R. Bar-On \& J.D.A. Parker (Eds.), Handbook of emotional intelligence: Theory, development, assessment, and application at home, school and in the workplace (pp. 363-388). San Francisco: Jossey-Bass Inc.

Bass, B.M. (1960). Leadership, psychology, and organisational behaviour. New York: Harper.

Bass, B.M. (1990). Bass and Stogdill's handbook of leadership. New York: Free Press.

Brackett, M.A., \& Geher, G. (2006). Measuring emotional intelligence: Paradigmatic diversity and common ground. In J. Ciarrochi, J.P. Forgas, \& J.D. Mayer (Eds.) Emotional intelligence and everyday life (pp. 27-50). New York: Psychology Press.

Brackett, M.A., Mayer, J.D., \& Warner, R.M. (2004). Emotional intelligence and its relation to everyday behaviour. Personality and Individual Differences, 36, 1387-1402. http://dx.doi.org/10.1016/S0191-8869(03)00236-8
Brown, T.A. (2006). Confirmatory factor analysis for applied research. New York, NY: Guilford Press.

Butler, C., \& Chinowsky, P. (2006). Emotional intelligence and leadership behavior in construction executives. Journal of Management in Engineering, 22(3), 119-125. http://dx.doi.org/10.1061/(ASCE)0742-597X(2006)22:3(119)

Dasborough, M., Todorova, G., \& Qu, Y. (2014). The dark side of authentic leadership: Leading dissimilar followers through conflict. In L.K. Neider \& C.A. Schrieshein (Eds.), Advances in authentic and ethical leadership (pp. 95-125), Charlotte, NC: Information Age Publishing, Inc.

Davies, K.A., Lane, A.M., Devonport, T.J., \& Scott, J.A. (2010). Validity and reliability of a Brief Emotional Intelligence Scale (BEIS-10). Journal of Individual Differences, 31(4), 198-208. http://dx.doi.org/10.1027/1614-0001/a000028

Diddams, M., \& Chang, G.C. (2012). Only human: Exploring the nature of weakness in authentic leadership. The Leadership Quarterly, 23, 593-603. http://dx.doi. org/10.1016/j.leaqua.2011.12.010

Eagly, A.H. (2005). Achieving relational authenticity in leadership: Does gender matter? The Leadership Quarterly, 16, 459-474. http://dx.doi.org/10.1016/j. leaqua.2005.03.007

Emuwa, A. (2013). Authentic leadership: Commitment to supervisor, follower empowerment, and procedural justice climate. Emerging Leadership Journeys, 6 45-65.

Field, A. (2005). Discovering statistics using SPSS. (2nd edn.). Thousand Oaks, CA: Sage.

Fiori, M., Antonietti, J-P., Mikolajczak, M., Luminet, O., Hansenne, M., \& Rossier, J. (2014). What is the Ability Emotional Intelligence Test (MSCEIT) good for? An evaluation using item response theory. Public Library of Science One, 9(6), e98827. PMID: 24901541, http://dx.doi.org/10.1371/journal.pone.0098827

Gardner, W.L., Avolio, B.J., Luthans, F., May, D.R., \& Walumbwa, F. (2005). "Can you see the real me?" A self-based model of authentic leader and follower development. The Leadership Quarterly, 16, 343-372. http://dx.doi.org/10.1016/j.leaqua. 2005.03.003

Gardner, W.L., Cogliser, C.C., Davis, K.M., \& Dickens, M.P. (2011). Authentic leadership: A review of the literature and research agenda. The Leadership Quarterly, 22(6), 1120-1145. http://dx.doi.org/10.1016/j.leaqua.2011.09.007

Gardner, W.L., Fischer, D., \& Hunt, J.G. (2009). Emotional labor and leadership: A threat to authenticity? The Leadership Quarterly, 20(3), 466-482. http://dx.doi. org/10.1016/j.leaqua.2009.03.011

Goleman, D. (1995). Emotional intelligence. New York: Bantam.

Goleman, D. (1998). Working with emotional intelligence. New York: Bantam.

Goleman, D., Boyatzis, R., \& McKee, A. (2002) The new leaders. Transforming the art of leadership into the science of results. London: Time Warner Books.

Hair, J.F., Black, B., Babin, B., Anderson, R.E., \& Tatham, R.L. (2006). Multivariate data analysis (6th edn.). New Jersey: Prentice Hall.

Hmieleski, K.M., Cole, M.S., \& Baron, R.A. (2012). Shared authentic leadership and new venture performance. Journal of Management, 38(5), 1476-1499. http:// new venture performance. Journal of $M$
dx.doi.org/10.1177/0149206311415419

Hopkins, M.M., O’Neil, D.A., \& Williams, H.W. (2007). Emotional intelligence and board governance: Leadership lessons from the public sector. Journal of Managerial governance: Leadership lessons from the public sector. Journal of Manag
Psychology, 22(7), 683-700. http://dx.doi.org/10.1108/02683940710820109

Hu, L., \& Bentler, P.M. (1999). Cutoff criteria for fit indexes in covariance structure analysis: Conventional criteria versus new alternatives. Structural Equation Modeling: A Multidisciplinary Journal, 6, 1-55. http://dx.doi.org/10.1080/ 10705519909540118

Humphrey, R.H., Pollack, J.M., \& Hawver, T. 2008. Leading with emotional labor. Journal of Managerial Psychology, 23(2), 151-168. http://dx.doi. org/10.1108/02683940810850790

Ilies, R., Morgeson, F.P., \& Nahrgang, J.D. (2005). Authentic leadership and eudaemonic well-being: Understanding leader-follower outcomes. The Leadership Quarterly, 16, 373-394. http://dx.doi.org/10.1016/j.leaqua.2005.03.002

Jöreskog, K.G., \& Sörbom, D. (2006). LISREL 8.80 for Windows [Computer Software]. Lincolnwood, IL: Scientific Software International, Inc.

Joseph, D.L., \& Newman, D.A. (2010). Discriminant validity of self-reported emotional intelligence: A multitrait-multisource study. Educational and Psychological Measurement, 70(4), 672-694. http://dx.doi.org/10.1177/0013164409355700

Kellett, J.B., Humphrey, R.H., \& Sleeth, R.G. (2006). Empathy and the emergence of task and relations leaders. The Leadership Quarterly, 17, 146-162. http://dx.doi. org/10.1016/j.leaqua.2005.12.003

Kiyani, K., Saher, N., Saleem, S., \& Iqbal, M. (2013). Emotional intelligence (EI) and employee outcomes: The mediating effect of authentic leadership style. Interdisciplinary Journal of Contemporary Research in Business, 5(1), 394-405.

Lawler,J., \&Ashman, I. (2012). Theorizingleadershipauthenticity:ASartrean perspective. Leadership, 8(4), 327-344. http://dx.doi.org/10.1177/1742715012444685

Liu, H., Cutcher, L., \& Grant, D. (2015). Doing authenticity: The gendered construction of authentic leadership. Gender, Work and Organization, 22(3), 237-255. http:// dx.doi.org/10.1111/gwao.12073

Luthans, F., \& Avolio, B.J. (2003). Authentic leadership development. In K.S. Cameron, J.E. Dutton, \& R.E. Quinn (Eds.), Positive organisational scholarship: Foundations of a new discipline (pp. 241-261). San Francisco: Barrett-Koehler.

Mahsud, R., Yukl, G., \& Prussia, G. (2010). Leader empathy, ethical leadership, and relations-oriented behaviors as antecedents of leader-member exchange quality. Journal of Managerial Psychology, 25(6), 561-577. http://dx.doi. org/10.1108/02683941011056932 
Maldonado, T.M. (2012). Managing conflict from the heart: Healthcare leaders' approaches in transforming conflict into better patient care. Masters of Arts Degree. Fresno, CA: The Graduate Faculty of Fresno Pacific University.

Mandell, B., \& Pherwani, S. (2003). Relationship between emotional intelligence and transformational leadership style: A gender comparison. Journal of Business and Psychology, 17, 387-404. http://dx.doi.org/10.1023/A:1022816409059

Muyia, H.M. (2009). Approaches to and instruments for measuring emotional intelligence: A review of selected literature. Advances in Developing Human Resources, 11(6), 690-702.

Mikolajczak, M. (2009). Going beyond the ability-trait debate: The three-level mode of emotional intelligence. Journal of Applied Psychology, 5(2), 25-31. http:// dx.doi.org/10.7790/ejap.v5i2.175

Müceldili, B., Turan, H., \& Erdil, O. (2013). The influence of authentic leadership on creativity and innovativeness. Procedia - Social and Behavioral Sciences, 99, 673681. http://dx.doi.org/10.1016/j.sbspro.2013.10.538

Petridges, K.V., \& Furnham, A. (2001). Trait emotional intelligence: Psychometric investigation with reference to established trait taxonomies. European Journal of Personality, 15(6), 425-448. http://dx.doi.org/10.1002/per.416

Peus, C., Wesche, J.S., Streicher, B., Braun, S., \& Frey, D. (2012). Authentic leadership: An empirical test of its antecedents, consequences, and mediating mechanisms.
Journal of Business Ethics, 107, 331-348. http://dx.doi.org/10.1007/s10551-011Journal

Price Waterhouse Coopers. (2014). Global economic crime survey: Confronting the changing face of economic crime. (4th South African edn.). Retrieved January 22 2015, from www.pwc.co.za/crimesurvey

Rahim, M.A., Psenicka, C., Polychroniou, P., Zhao, J.-H., Yu, C.-S., \& Chan, K.A., et al (2002). A model of emotional intelligence and conflict management strategies: A study in seven countries. The International Journal of Organisational Analysis, 10(4), 302-326. http://dx.doi.org/10.1108/eb028955

Rego, A., Sousa, F., Marques, C., \& Cunha, M.P.E. (2012). Authentic leadership promoting employees' psychological capital and creativity. Journal of Business Research, 65(3), 429-437. http://dx.doi.org/10.1016/j.jbusres.2011.10.003

Riggio, R.E., \& Reichard, R.J. (2008). The emotional and social intelligences of effective leadership: An emotional and social skill approach. Journal of Managerial Psychology, 23(2), 169-185. http://dx.doi.org/10.1108/02683940810850808
Rubin, R.S., Munz, D.C., \& Bommer, W.H. (2005). Leading from within: The effects of emotion recognition and personality on transformational leadership behavior. Academy of Management Journal, 48(5), 845-858. http://dx.doi.org/10.5465/ AMJ.2005.18803926

Sadri, G., Weber, T.J., \& Gentry, W.B. (2011). Empathic emotion and leadership performance: An empirical analysis across 38 countries. The Leadership Quarterly, 22, 818-830. http://dx.doi.org/10.1016/j.leaqua.2011.07.005

Salovey, P., \& Mayer, J.D. (1990). Emotional intelligence. Imagination, Cognition and Personality, 9(3), 185-211. http://dx.doi.org/10.2190/DUGG-P24E-52WK6CDG

Schmitt, N. (1994). Method bias: The importance of theory and measurement. Journal of Organizational Behavior, 15, 393-398. http://dx.doi.org/10.1002/ job.4030150504

Tett, R.P., Fox, K.E., \& Wang, A. (2005). Development and validation of a selfreport measure of emotional intelligence as a multidimensional trait domain. Personality and Social Psychology Bulletin, 31(7), 859-888. http://dx.doi. org/10.1177/0146167204272860

Tredoux, C., \& Durrheim, K. (2002). Numbers, hypotheses, and conclusions: A course in statistics for the social sciences. Lansdowne, Cape Town: UCT Press.

Van Rooy, D.L., Alonso, A., \& Viswesvaran, C. (2005). Group differences in emotional intelligence scores: Theoretical and practical implications. Personality and Individual Differences, 38, 689-700. http://dx.doi.org/10.1016/j.paid.2004. 05.023

Vläsceanu, S. (2012). Leadership and emotional intelligence in the context of organisational dynamics. Romanian Journal of Experimental Applied Psychology, 3(1), 43-50.

Walter, F., Cole, M.S., \& Humphrey, R.H. (2011). Emotional intelligence: Sine qua non of leadership or folderol? Academy of Management Perspectives, 25, 45-59.

Walumbwa, F.O., Avolio, B.J., Gardner, W.L., Wernsing, T.S., \& Peterson, S.J. (2008). Authentic leadership: Development and validation of a theory-based measure. Journal of Management, 34(1), 89-126. http://dx.doi.org/10.1177/ 0149206307308913

Zeng, X., \& Miller, C.E. (2003). Examinations of measurements of emotional intelligence. Ergometrika, 2, 38-49. 